\title{
Influences of Short -term Aerobic Exercise and Supplementation of Carnitine With or Without Choline on Body Weight, Serum Leptin and Carnitine as Well as Lipid Status In Male Rats
}

\author{
Neamat E. Hishem*, Bushra H. El-Zawahry*, Seham M.S. El Nakeeb** and \\ Layla A. Ahmad** \\ Physiology* and Biochemistry** Departments, Faculty of Medicine for Girls, \\ Al- Azhar University
}

\begin{abstract}
Background: Carnitine is essential for fatty acids translocation, muscles function and exercise performance. Choline is a lipotropic agent that prevents deposition of fat in the liver. The studies concerning the effects of carnitine and choline supplementation with exercise on carnitine status and serum leptin are rare. The aim of the present study was to study the effect of carnitine and its combination with choline, with or without exercise on body and total fat pad (TFP) weights, serum carnitine, leptin, $\beta$-hydroxy butyric acid ( $\beta$-HBA), triacylglycerols (TAG) and Free Fatty acids (FFA). Also, total lipids (TL) and TAG content of TFP and urinary carnitine were investigated.

Material and Methods: 48 male rats were equally divided to the following groups: control (C), carnitine $(5 \mathrm{~g} / \mathrm{Kg}$ diet) supplemented, carnitine plus choline $(5$ and $11.5 \mathrm{~g} / \mathrm{Kg}$ diet respectively) supplemented. Half of each group was subjected to short term aerobic exercise on manual treadmill, in which the speed and duration were gradually increased via the course of the experiment, to be $10 \mathrm{~m} / \mathrm{min}$ for $20 \mathrm{~min} /$ day, 5 days/week in the last 2 weeks. Body weights were recorded weekly. After 6 weeks, The 24 hours urine was collected then the fasted rats were sacrificed and blood and the total fat pad (TFP) were collected for analysis.

Results: Carnitine supplementation, tended to decrease body weight, TFP, TAG content and serum FFA, and significantly decreased the TL content, serum leptin, TAG $(\mathrm{P}<0.0005)$. Carnitine feeding resulted in a significant elevation of serum carnitine, $\beta$-HBA and urinary carnitine $(\mathrm{P}<0.0005)$, compared to sedentary control rats. These values became more pronounced on choline addition to the diet except for serum and urinary carnitine that reversed (i.e. decreased) by choline addition. Exercise intervention resulted in a significant decrease in body weight, TFP, TL content and serum leptin, TAG and FFA. These values were more pronounced in both supplements with exercise, specially serum carnitine. However, exercise caused reduction of urinary carnitine in non-supplemented and carnitine supplemented groups and this was reversed by choline and exercise.

Conclusion: Our study demonstrated that the beneficial effects of carnitine supplements is promoted by choline with or without mild exercise to reduce body weight, body fat, serum leptin and promote fat loss by increasing lipolysis as indicated by increased serum $\beta$-HBA. These results may or may not be applicable to humans, so further research is recommended to determine whether similar effects would result in humans or not.
\end{abstract}

Key words: Carnitine . choline . leptin . $\beta$-hydroxy butyric acid . total lipids . exercise

\section{Introduction}

L-carnitine, is a naturally occurring substance found in most cells of the body, particularly the brain and neural tissues, muscles, and heart. Carnitine, whose structure is similar to choline, is widely available in animal foods (meat, poultry, fish and dairy products), whereas plants have very small amounts (Iossa et $a l ., 2002)$. A number of studies in a variety of species have shown that, carnitine supplementation influences body composition (Heo et al., 2000). It is conceivable 
that, carnitine is a co-factor of the enzymatic system involved in long-chain fatty acid transport across the mitochondrial membrane. Also the physiological role of carnitine rose to the hypothesis that, this compound could act as a fat burner by optimizing fat oxidation and a consequently reducing its availability for storage (Saldanda et al., 2004). Several studies observed an increase in carnitine utilization during endurance exercise in human (Bross \& Hiatt 2004 and Saldanda et al., 2004).

Choline is a lipotropic agent that prevents deposition of fat in the liver. It is an essential nutrient for humans, providing structure to cell membranes and facilitating transmembrane signaling as well as synthesis and release of acetylcholine. The potential use of choline supplementation for improving physical performance has been reported by many investigators (Decombaz et al., 1999 and Leiber et al., 2002). On the other hand, choline supplementation to dietary food leads to an increase in fatty acid oxidation and decrease in the total lipids and body weight. These effects will be enhanced by combination of supplementation with mild muscular exercise (Hongu and Sachan 2003). However other study reported that choline-supplemented diet resulted in reduction in the percentage of body fat and increase in the percentage of protein without significantly changing bodyweight (Daily et al., 1998). Also, Dodson and Sachan (2004), reported that, choline supplementation resulted in significant conservation of body carnitine in humans and guinea pigs, this may promote tissue carnitine accretion particularly in skeletal muscle. Combined dietary supplementation of carnitine and choline resulted in an increase in fatty acid oxidation and reduction in the total lipids and body fat. However their combined effect with exercise is controversial (Hongu and Sachan, 2005).

Leptin is a hormone secreted by adipocytes. It may contribute to long-term control of energy balance and body composition by interaction with receptors in the hypothalamus. It circulates in proportion to body fat in both human and rodents (Robert et al., 2002 and Flores et al., 2006) .Other sites have been identified as a source of leptin including: skeletal muscle , mammary epithelium, placenta and brain. It plays a central role in the regulation of fatty acid homeostasis, promotion of lipid storage in adipose tissues and fatty acid oxidation in the peripheral tissues. On the other hand, loss of leptin in signaling leads to accumulation of lipid in muscle and loss of insulin sensitivity secondary to obesity (Mcclell et al., 2004). It is thought that, the major role of leptin is to relay information to signal transducing receptors in the hypothalamus concerning the status of energy stores and thus aid in reduced feeding its receptors including hypothalamic nuclei (Ahima and Flier, 2000). Leptin receptor mutations cause early obesity in both humans and rats. It is regulated by fat storage with larger adipocytes containing more leptin than smaller ones, and also regulated by insulin level (Saladin et al., 1999). The studies concerning the nutritional factors that influence circulating leptin concen-trations are little specially with exercise. Thus in light of these observations, we proposed that carnitine either alone or with choline supplementation, with or without short term aerobic exercise would alter carnitine status ,serum leptin, body fat and the biochemical marker of fat oxidation, represented by $\beta$-HBA, in male rats.

\section{Material and Methods}

Chemicals used:

- Carnitine powder was supplemented from Faculty of Science Al-Azhar University as a gift (Sigma, St. Louis, MD).

- Choline powder was purchased from El-Gomhorea-Co for Chemicals.

\section{Experimental design:}

Forty-eight adult male albino rats were obtained from Helwan Breeding farm, their initial body weights ranged from 200$215 \mathrm{~g}$. They were fed on ordinary rat show (balanced diet: $22 \%$ protein, $5 \%$ fat, 
69.62\% $\mathrm{CHO}$ and $3.38 \%$ fiber) and water ad-libitum. They were allowed to stay for two weeks in the animal house for accommodation prior to the experiment, and then animals were randomly assigned into three groups (16 each):

- Control group.

- Carnitine supplemented group in a dose of $5 \mathrm{~g} / \mathrm{kg}$ diet (Hongu and Sachan, 2005).

- Carnitine plus choline supplemented group, $5 \mathrm{~g} / \mathrm{kg}$ diet and $11.5 \mathrm{~g} / \mathrm{kg}$ diet respectively (Hongu and Sachan, 2005).

-Half of each group (8 rats) was subjected to short term aerobic exercise program throughout the experiment period (6 weeks).

-Body weights were measured weekly for all groups

\section{Exercise protocol:}

Exercise was performed for the exercise groups by a manual treadmill made in the department of physiology in Faculty of Medicine for Girls, Al-Azhar University. The apparatus consists of a metal cage $(40 \quad \mathrm{X} 30 \times 40 \mathrm{~cm}$.) with a movable base. This base made of natural leather rolled on two wheels, one on each side. One of the two wheels is attached to a hand via which the base of the cage is moved manually. The cage is divided longitudinally by a wall, so it can accommodate 2 rats at the same time. The maximum speed reached is $10 \mathrm{~meter} / \mathrm{min}$.

All animals in the exercise groups were subjected to run on the treadmill starting with $5 \mathrm{~min} /$ day during the period of accommodation. At the beginning of the experiment, the running speed and duration were continuously increased during the course of exercise, starting with $5 \mathrm{~m} / \mathrm{min}$ for $5 \mathrm{~min} /$ day to reach the maximum speed $(10 \mathrm{~m} / \mathrm{min}$ for $20 \mathrm{~min} /$ day $)$ during the last 2 weeks. The exercise sessions were repeated 5 days/week for 6week.

\section{Urine collection:}

Twenty four hours urine was collected, by using metabolic cages, one day before sacrificing the animals, for determination of acetyl carnitine content.
The urine samples were centrifuged at $1500 \mathrm{x}$ g for $10 \mathrm{~min}$ at $4^{\circ} \mathrm{C}$, then stored immediately at $-70{ }^{\circ} \mathrm{C}$ until analysis.

\section{Blood sampling:}

At the end of the experiment, all overnight fasting animals were sacrificed by decapitation under light ether anesthesia, and blood samples were collected from carotid artery, centrifuged at $3000 \mathrm{rpm}$ for $(10 \mathrm{~min})$. Sera were separated and stored at $-70^{\circ} \mathrm{C}$ until used for analysis.

\section{Total fat pad:}

(inguinal, perineal and epididymal) were excised and weighed, rinsed with saline, blotted dry then stored at $-70^{\circ} \mathrm{C}$ until used for determination of triacylglycerols (TAG) and total lipid (TL) contents.

\section{Biochemical analysis:}

- Serum leptin concentrations were measured using a commercial radioimmunoassay (RIA)kit (Linco Research, Inc, St. Charles, MO) using a ${ }^{125}$ I-iodinated human leptin tracer and antihuman leptin rabbit polyclonal antibody (Ma, Zhongmin et al., 1996).

-Serum triacylglycerols (TAG), total lipid (TL) and FFA were determined by the methods of Gielgel et al. (1975), Ellefson and Caraway (1976) and Novak (1965) respectively.

- Serum $\beta$-hydroxybutyric acid $(\beta$ HBA) was determined by NAD + linked enzymatic reactions ,spectrophotometrically, at $340 \mathrm{~nm}$ (Sigma kit no. 310, Sigma, St. Louis Mo.).

-Serum and urine carnitine were measured by the method of Cederblad and Lindstedt (1972) .

\section{Statistical analysis}

The data are expressed as means $\pm \mathrm{SE}$ by using two-way ANOVA to test the effects of supplementation and exercise using SAS (1997). Differences were considered significant at $\mathrm{P}<0.05$. The 
superscript letters indicate significant differences among the groups.

\section{Results}

Table $1 \&$ Figure 1 demonstrated the changes in body weights gain, total fat pad (TFP) weights and total lipid (TL) and triacylglycerols (TAG) contents of TFP in different groups. Carnitine supplementation resulted in tendency to decrease $(\mathrm{P}>0.05)$ in body weight and TFP. These decreases became significant on addition of choline. While both supplements resulted in significant reduction of the TL $(\mathrm{P}<0.0005)$ contents and insignificant decrease in TAG contents compared to sedentary control group. Exercise intervention for all groups caused significant decrease in body weights, TFP weights and TL contents and insignificant changes in TAG compared to sedentary rats either supplemented or nonsupplemented.

Table $2 \&$ Figures $2-5$ demonstrated the changes in serum carnitine, leptin, $\beta$ HBA, TAG, FFA and urinary carnitine in different groups. Carnitine supplementation resulted in a significant elevation of serum carnitine and $\beta$-HBA $(\mathrm{P}<0.0005)$ and a significant reduction in serum leptin and TAG $(\mathrm{P}<0.0005)$ with tendency to decrease in FFA. These changes became more pronounced by choline addition and exercise compared to sedentary control rats. On the other hand carnitine feeding increased urinary carnitine $(\mathrm{P}<0.0005)$ while choline addition was significantly decreased serum and urinary carnitine. Exercise with carnitine and choline supplementation led to further decrease in serum carnitine but increased urinary carnitine significantly $\quad(\mathrm{P}<0.0005)$ compared to sedentary rats either supplemented or non-supplemented.

Table (1): Mean \pm SE of body weight gain, total fat pad weight, and the content of total lipid and triacylglycerols in total fat pad in different groups.

\begin{tabular}{|l|c|c|c|c|c|c|}
\hline \multicolumn{1}{|c|}{ Group } & \multicolumn{2}{|c|}{ Control } & \multicolumn{2}{c|}{ Carnitine supplemented } & \multicolumn{2}{c|}{$\begin{array}{c}\text { Carnitine + choline } \\
\text { supplemented }\end{array}$} \\
\hline \multicolumn{1}{|c|}{ Parameter } & Sedentary & Exercised & Sedentary & Exercised & Sedentary & Exercised \\
\hline Body weight gain (g) & $110.6 \pm 5.3^{\mathrm{a}}$ & $75.3 \pm 6.2^{\mathrm{c}}$ & $105 \pm 6.4^{\mathrm{ab}}$ & $70.3 \pm 5.8^{\mathrm{c}}$ & $93.5 \pm 4.2^{\mathrm{b}}$ & $65.8 \pm 6.2^{\mathrm{c}}$ \\
& & $\mathrm{P}<0.005$ & $\mathrm{P}>0.05$ & $\mathrm{P}<0.0005$ & $\mathrm{P}<0.05$ & $\mathrm{P}<0.0005$ \\
\hline Total fat pad weight (g) & $13.3 \pm 0.83^{\mathrm{a}}$ & $9.5 \pm 0.85^{\mathrm{c}}$ & $11.5 \pm 0.81^{\mathrm{ab}}$ & $7.4 \pm 0.58^{\mathrm{d}}$ & $10.1 \pm 0.76^{\mathrm{b}}$ & $7.2 \pm 0.65^{\mathrm{d}}$ \\
& & $\mathrm{P}<0.0025$ & $\mathrm{P}>0.05$ & $\mathrm{P}<0.0005$ & $\mathrm{P}<0.005$ & $\mathrm{P}<0.0005$ \\
\hline Total lipid (g) & $9.8 \pm 0.82^{\mathrm{a}}$ & $6.2 \pm 0.28^{\mathrm{b}}$ & $7.1 \pm 0.23^{\mathrm{c}}$ & $5.4 \pm 0.15^{\mathrm{d}}$ & $6.8 \pm 0.35^{\mathrm{c}}$ & $5.2 \pm 0.31^{\mathrm{d}}$ \\
& & $\mathrm{P}<0.0005^{2}$ & $\mathrm{P}<0.0005$ & $\mathrm{P}<0.0005$ & $\mathrm{P}<0.0005$ & $\mathrm{P}<0.0005$ \\
\hline Triacylglycerols & $8.9 \pm 0.48^{\mathrm{a}}$ & $8.2 \pm 0.45^{\mathrm{a}}$ & $7.8 \pm 0.6^{\mathrm{a}}$ & $8.1 \pm 0.78^{\mathrm{a}}$ & $8.2 \pm 0.82^{\mathrm{a}}$ & $7.7 \pm 0.68^{\mathrm{a}}$ \\
\hline (mmol/g. fat) & & $\mathrm{P}>0.05$ & $\mathrm{P}>0.05$ & $\mathrm{P}>0.05$ & $\mathrm{P}>0.05$ & $\mathrm{P}>0.05$ \\
\hline
\end{tabular}

-Value with different letters in a row differ significantly $(\mathrm{P}<0.05)$.

-The $\mathrm{P}$ - value mentioned is compared to sedentary control. 
Table (2): Mean \pm SE of serum carnitine, leptin, $\beta$-HBA, TAG, FFA and urinary carnitine in different groups.

\begin{tabular}{|c|c|c|c|c|c|c|}
\hline Group & \multicolumn{2}{|c|}{ Control } & \multicolumn{2}{|c|}{ Carnitine supplemented } & \multicolumn{2}{|c|}{$\begin{array}{c}\text { Carnitine + choline } \\
\text { supplemented }\end{array}$} \\
\hline Parameter & Sedentary & Exercised & Sedentary & Exercised & Sedentary & Exercised \\
\hline $\begin{array}{l}\text { Serum carnitine } \\
\qquad(\mu \mathrm{mol} / \mathrm{L})\end{array}$ & $39.2 \pm 2.5^{\mathrm{a}}$ & $\begin{array}{l}37.3 \pm 2.6^{\mathrm{ac}} \\
P>0.05\end{array}$ & $\begin{array}{l}57.8 \pm 2.8^{b} \\
P<0.0005\end{array}$ & $\begin{array}{l}62.6 \pm 3.1^{b} \\
P<0.0005\end{array}$ & $\begin{array}{l}32 \pm 2.1^{\mathrm{c}} \\
\mathrm{P}<0.05\end{array}$ & $\begin{array}{l}24.9 \pm 2.2^{\mathrm{e}} \\
\mathrm{P}<0.0005\end{array}$ \\
\hline $\begin{array}{c}\text { Serum leptin } \\
(\mu \mathrm{g} / \mathrm{ml})\end{array}$ & $2.31 \pm 0.11^{\mathrm{a}}$ & $\begin{array}{l}1.9 \pm 0.02^{b} \\
P<0.0005\end{array}$ & $\begin{array}{l}1.82 \pm 0.1^{b} \\
P<0.0005\end{array}$ & $\begin{array}{c}1.42 \pm 0.05^{\mathrm{c}} \\
\mathrm{P}<0.0005\end{array}$ & $\begin{array}{l}1.61 \pm 0.04^{\mathrm{d}} \\
\mathrm{P}<0.0005\end{array}$ & $\begin{array}{l}1.15 \pm 0.08^{\mathrm{e}} \\
\mathrm{P}<0.0005\end{array}$ \\
\hline $\begin{array}{c}\beta-\text { HBA } \\
(\mu \mathrm{mol} / \mathrm{L})\end{array}$ & $21.3 \pm 2.1^{\mathrm{a}}$ & $\begin{array}{l}38.4 \pm 3.4^{b} \\
P<0.0005\end{array}$ & $\begin{array}{l}53.8 \pm 3.2^{c} \\
P<0.0005\end{array}$ & $\begin{array}{l}77.8 \pm 2.5^{\mathrm{d}} \\
\mathrm{P}<0.0005\end{array}$ & $\begin{array}{l}60 \pm 3.6^{\mathrm{e}} \\
\mathrm{P}<0.0005\end{array}$ & $\begin{array}{c}85 \pm 2.8^{\mathrm{f}} \\
\mathrm{P}<0.0005\end{array}$ \\
\hline $\begin{array}{l}\text { Triacylglycerols } \\
(\mathbf{m m o l} / \mathbf{L})\end{array}$ & $0.79 \pm 0.03^{\mathrm{a}}$ & $\begin{array}{l}0.72 \pm 0.03^{\mathrm{ab}} \\
\mathrm{P}>0.05\end{array}$ & $\begin{array}{c}0.65 \pm 0.04^{\mathrm{b}} \\
\mathrm{P}<0.0005\end{array}$ & $\begin{array}{c}0.53 \pm 0.03^{\mathrm{c}} \\
\mathrm{P}<0.0005\end{array}$ & $\begin{array}{c}0.46 \pm 0.03^{\mathrm{cd}} \\
\mathrm{P}<0.0005\end{array}$ & $\begin{array}{c}0.43 \pm 0.02^{\mathrm{d}} \\
\mathrm{P}<0.0005\end{array}$ \\
\hline FFA $(\mathrm{mmol} / \mathrm{L})$ & $275.2 \pm 18.3^{\mathrm{a}}$ & $\begin{array}{l}285.3 \pm 16.2^{\mathrm{a}} \\
\quad P>0.05\end{array}$ & $\begin{array}{l}245.8 \pm 17.3^{\mathrm{a}} \\
\quad \mathrm{P}>0.05\end{array}$ & $\begin{array}{c}169.7 \pm 9.5^{b} \\
P<0.0005\end{array}$ & $\begin{array}{c}179.4 \pm 10.3^{b} \\
P<0.0005\end{array}$ & $\begin{array}{c}142.8 \pm 8.5^{c} \\
P<0.0005\end{array}$ \\
\hline $\begin{array}{l}\text { Urinary carnitine } \\
\qquad(\mu \mathrm{mol} / \mathrm{L})\end{array}$ & $145.5 \pm 3.8^{\mathrm{a}}$ & $\begin{array}{l}65.3 \pm 8.6^{b} \\
P<0.0005\end{array}$ & $\begin{array}{c}335.8 \pm 18.5^{\mathrm{c}} \\
\mathrm{P}<0.0005\end{array}$ & $\begin{array}{c}205.6 \pm 11.3^{d} \\
P<0.0005\end{array}$ & $\begin{array}{c}55.8 \pm 4.2^{b} \\
P<0.0005\end{array}$ & $\begin{array}{l}155 \pm 3.2^{\mathrm{e}} \\
\mathrm{P}<0.0005\end{array}$ \\
\hline
\end{tabular}

-Value with different letters in a row differ significantly $(\mathrm{P}<0.05)$.

-The $\mathrm{P}$ - value mentioned is compared to sedentary control.

Fig (1): Mean of body weight gain in different groups.

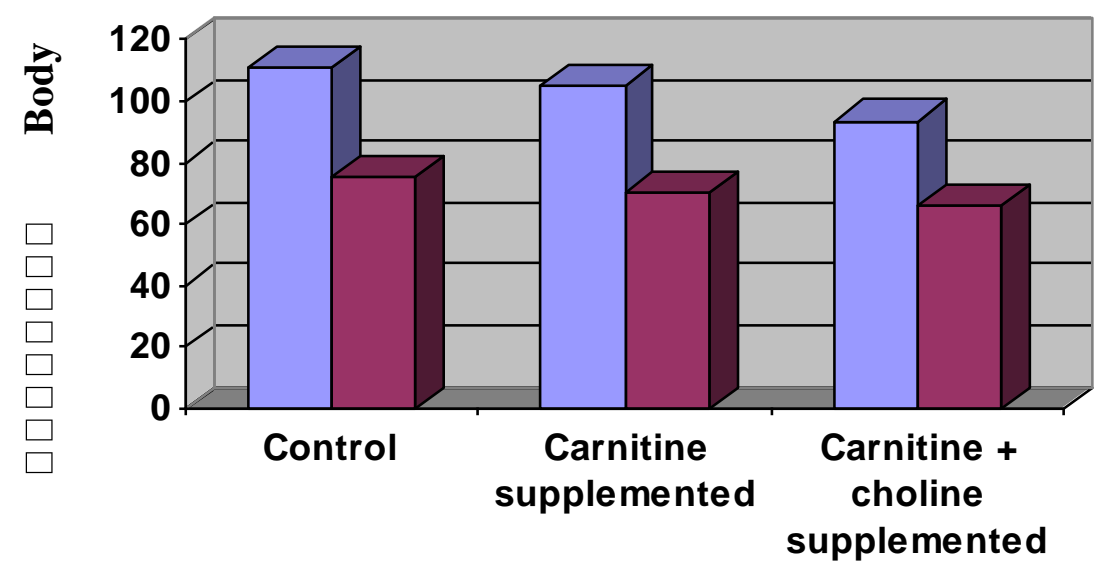


Fig (2): Mean of serum carnitine in different groups.

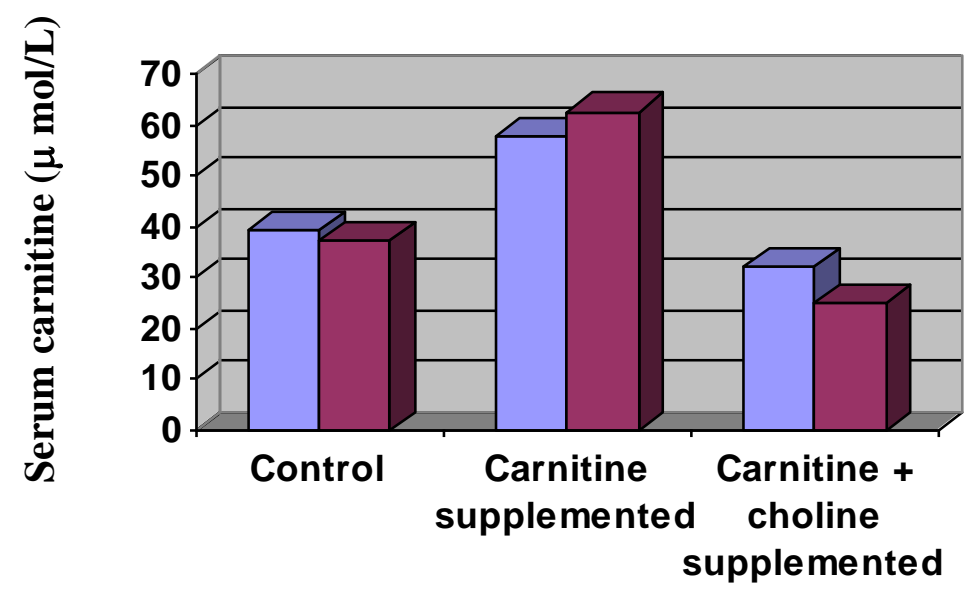

Fig (3): Mean of urinary carnitine in different groups.

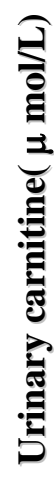

כ]

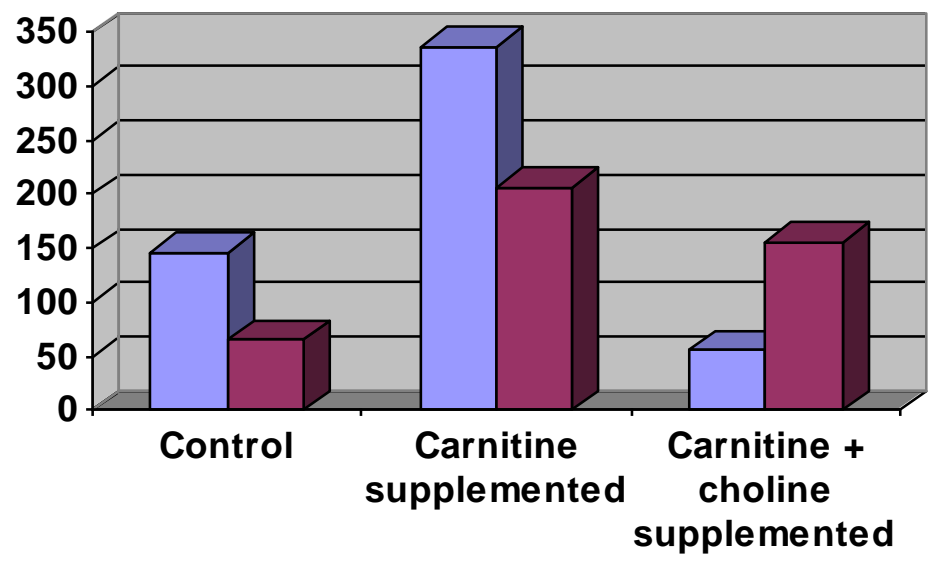


Fig (4): Mean of serum leptin in different groups.

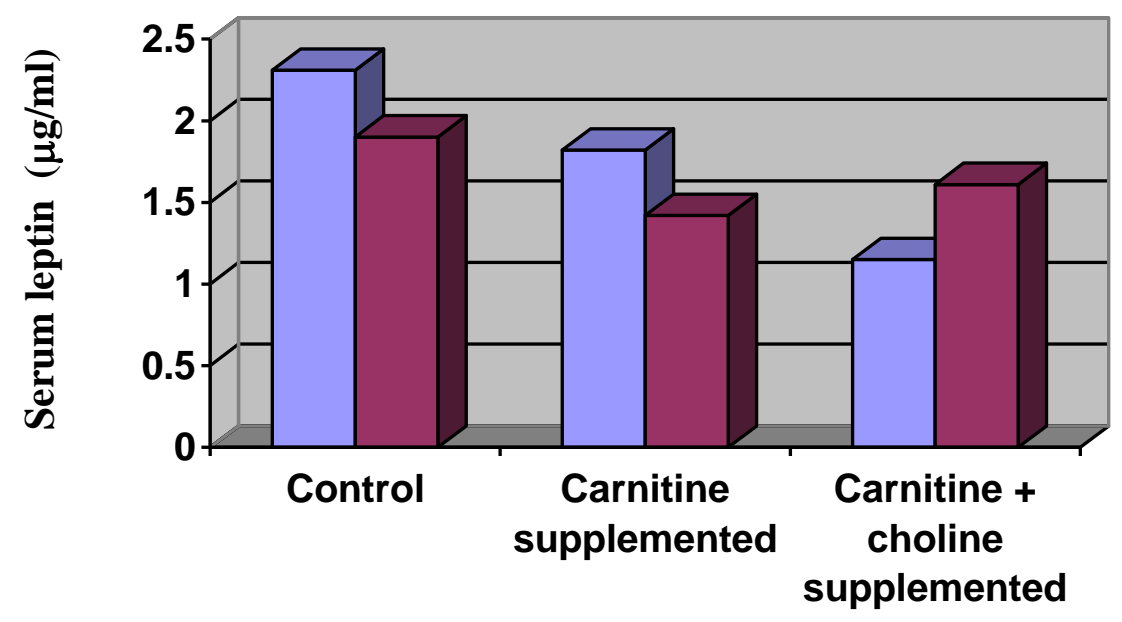

$\square$ Sedentary

$\square$ Exercised

Fig (5): Mean of serum $\beta$-HBA in different groups.

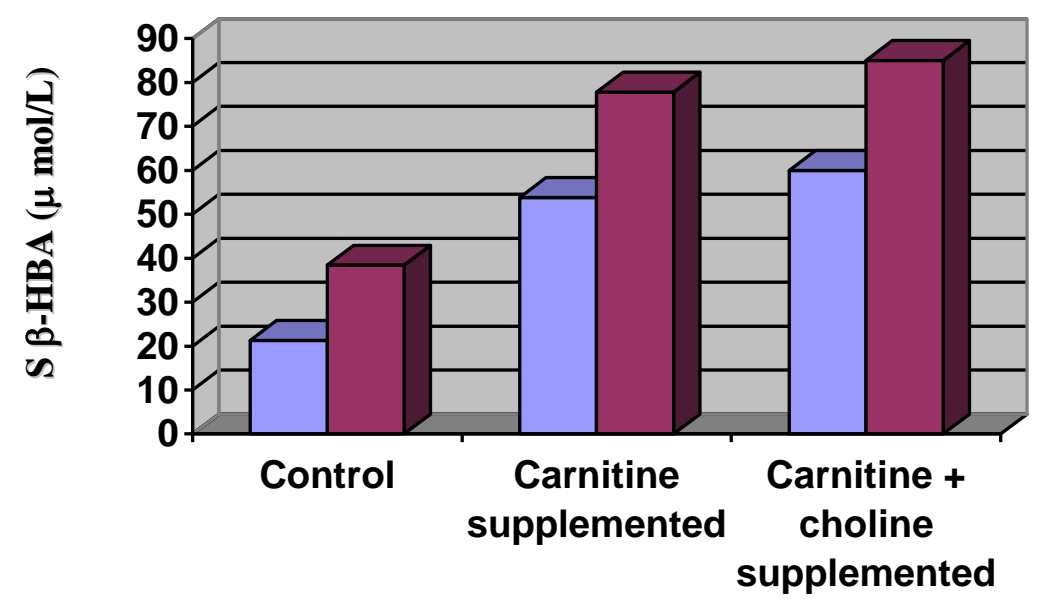

$\square$ Sedentary

Exercised

\section{Discussion}

Exercise training is known to induce physiological adaptations that improve exercise performance and alter patterns of energy substrate utilization to favor fatty acid oxidation. L-carnitine is an essential cofactor for the oxidation of fatty acids under all physiological conditions, includeing exercise (Levin and Meynell, 2006). The current study evaluated the effect of short term exercise and carnitine with or without choline supplementation on body and total fat pad weights, serum carnitine, leptin, $\beta$-HBA, TAG and FFA. Also, total lipids and TAG content of TFP and urinary carnitine were investigated.

The present work showed a significant reduction in both body weights and fat pad weights in the rats supplemented with carnitine and those with carnitine combined with choline with or without short term aerobic exercise as compared to the sedentary control. These 
findings are in agreement with Hongu and Sachan (2005) who noticed that, physical exercises play a big role in promoting fat oxidation, consequently there is a reduction in the adipose fat mass and weight loss takes place. The combination of choline and carnitine superimposed with mild exercise was hypothesized to enhance oxidation of fat by skeletal muscle and as a consequence reduce the amount of body fat, while diets supplemented with carnitine alone have produced variable responses regarding substrate utilization and muscle fatigue in exercise (Dodson and sachan 2004). On the other hand, the reduction in the body weight, and fat mass may be due to the significant loss of adipose fat mass which enhanced by physical activity (Romijn et al., 1999 and Kimura et al., 2006). Neumann (2005) found that, diet supplemented with choline and carnitine together induces fatty acid oxidation which was enhanced following physical activity. This may be due to the effect of exercise on the mobilization of FFA by increasesing lipolysis which results from the inhibitory effect of postprandial hyperinsulinemia on lipolysis. Since choline and carnitine have been used as lipotropic agents in a number of studies, it was hypothesized that, their combined effect on fat metabolism may be greater than carnitine alone and may even be enhanced by physical activity where energy demand is increased (Daily and Sachan 2005). Also it was reported that, rats supplemented with choline and carnitine and superimposed by mild exercise for 4 weeks duration, induced a significant reduction of adipose fat when compared with non-exercised animals (Rein et al.,2002). In the present work, there was a significant reduction in the total lipid content of fat pads in all exercised rats supplemented with choline and carnitine with or without exercise as compared to the non-exercised- nonsupplemented rats. The combination of choline and carnitine with physical activity reduces body fat as indicated by a decrease in fat mass weights and total lipids, this can be attributed to the promotion of energy substrate utilization by supplementation under the condition of exercise. Mild exercise has been shown to promote preferential use of fat for energy needs over and above the basal requirement (Sahtin et al., 2006). Many studies have reported that, physical exercise resulted in reduction in the total and subcutaneous adipose tissues. The reduction in the body fat is supported by decreasing in the endogenous marker of adiposity, leptin, which was significantly lower in the rats supplemented with carnitine with or without choline as well as the exercised rats in our study. In addition, physical activity produce increasing in the phosphorylation activity of several proteins involved in leptin and insulin signal transduction in the combination of choline and carnitine in the hypothalamus (Robert et al. 2002 and Flores et al., 2006).

In the current study, it was found that, serum leptin showed a significant reduction in the supplemented groups which became more marked after exercise program, these findings were in agreement with the study of Ahima and Flier (2000) who reported the reduction in leptin concentration following physical activity as a result of changes in energy balance, also it is confirmed by more fat mass reduction during exercise, as the leptin concentration is positively correlated with body fat and body weight, and this is pronounced in our study. Most reports of reductions in serum leptin may attribute to circadian rhythms or hemoconcentration. On the other hand, physical activity produces a sufficient energy imbalance. The suppression of leptin level may be counter balanced by feeding, this may explain the reduction in leptin following extreme bouts of exercise such as marathons ( Janne et al.,2001 and Kraemer et al., 2002). Also leptin concentration can be regulated by insulin level in response to feeding. So during fasting, there is a decline in leptin level following reduction in insulin. Other hormones Such as glucocorticoids, growth hormone and catecholamines, lead to inhibition of leptin production in response to exercise (Commins et al., 2001). 


\section{Neamat E. Hishem et al}

In the present study, serum TAG and FFA levels showed a significant decrease in supplemented exercised groups as compared to the resting and exercised rats. On the contrary serum $\beta$-HBA showed a significant increase in both supplemented groups and further increased by exercise. These results were in agreement with Lau et al. (2001), who reported that both choline and carnitine improve physical performance and muscle function, also altered biochemical markers that were indicative of enhanced fatty acid oxidation to acetate and this is clear in our results, as there were complementary decreases in the serum TAG and FFA in the supplemented groups. Saldanda et al. (2004) suggested that, mild exercise enhanced fat utilization as energy substrate. This is reconfirmed in our results in both supplemented groups, but not in control group, as indicated by the increase in the $\beta$-HBA levels by exercise beyond that raised by the supplements alone. Couturier et al. (2004) found that, the increase in the $\beta$-HBA in the exercised rats may be resulted from the enhanced activity of lipogenic enzymes in adipose tissues, all are decreased following muscular activity. Also, Levin and Meynell (2006) speculated that, muscular activity produced increasing in $\beta$-HBA following dietary choline and carnitine supplementation which enhance fatty acid oxidation and mitochondrial events. Borges et al. (2005) speculated that, muscular activity resulted in increasing lipolysis, increasing the incorporation of palmitate esterification, decreasing the incorporation of acetate into lipids and diminishes the circulating leptin levels, all these changes can be attributed to the role of pineal gland in the regulation of lipid metabolism which cause physiological balance between lipogenesis and lipolysis during rest and alteration occur with muscular activity.

It is clear from our results that, serum carnitine concentration showed an insignificant increase in the exercised carnitine supplemented group as compared to the sedentary counterpart. On addition of choline to carnitine supplementation, serum carnitine level decreased significantly, and further decreased with exercise as compared to that of the sedentary and exercised controls. Urinary carnitine excretion showed a significant reduction in the exercised control and carnitine supplemented rats as compared to the resting groups. On addition of choline a significant decrease in the urinary carnitine was observed and this was reversed by exercise. This may be due to the increased demand for energy by exercise in choline/carnitine preloaded rats, leads to an increase in the rates of fatty acid oxidation, resulting in sustained loss of acyl groups in urine (Saldanda et al., 2004 and Sahtin, 2006). These findings were in line with the study of Neumann (2005) who found that, carnitine contents in the skeletal muscle increased by choline supplementation due to enhancement of carnitine entrance to the skeletal muscles by choline, with subsequent reduction in plasma carnitine levels. Also the decrease in serum carnitine by addition of choline may be due to conservative effect of choline which is in line with the study of Hongu and Sachan (2003), who observed that choline and carintine supplementation over normal dietary intakes altered serum and urinary carnitine profiles in women. Where choline supplementation for 1 wk conserved carnitine, as indicated by decreases in excretion of carnitine in urine similar to that seen in our study. This conservation would be expected to increase the plasma concentrations of carnitine, but it did not in this study. This may be due to a significant shift of carnitine into the tissues of animals supplemented with choline. It is reasonable, therefore, to expect that choline also promotes preferential portioning of carnitine into animal tissues. This explains the relative stability of carnitine concentrations in the plasma compartment of humans and animals in spite of dramatic decreases in urinary carnitine excretion that has been, for most part, accounted for by the tissue pool of carnitine. This is confirmed by Daily et al. (1998), who found that choline supplementation increases tissue concentration of carnitine and lowers body fat in Gina pigs. 


\section{Conclusion}

Our study demonstrated that the beneficial effects of carnitine supplement is promoted by choline with or without mild exercise to reduce body weight, body fat, serum leptin and promote fat loss by increasing lipolysis as indicated by increased serum $\beta$-HBA. These results may or may not be applicable to humans, so further research is recommended to determine whether similar effects would result in humans or not.

\section{References}

1. Ahi S and Flier, J (2000): Adipose tissues as an endocrine organ trends. Endocrinol Metab., 11: 327-31.

2. Borges C, Peres, $S$ and lima B (2005): Reduced lipolysis and increased lipogenesis in adipose tissues from pineal ectomized rats adapted to training. J. Pineal Res., 39(2): 179-4.

3. Bross, P and Hiatt, WR (2004) :Carnitine metabolism during exercise. Life Sci ., 54: 1383-93.

4. Cederblad G and Lindstedt S (1972): A method for determination of carnitine in the picomole range. Clin. Chim. Acta., 37:253-3.

5. Commins $\mathbf{P}$, Watson $M$ and Gettys $\mathbf{T}$ (2001): Leptin selectively reduces white adipose tissue in mice. Am $\mathbf{J}$ Physiol Endocrinol Metab; 280 (2):372-7

6. Couturier $\mathbf{K}$, Guigas $\mathbf{B}$, and Favier $\mathbf{R}$ (2004): Metabolic and hormonal responses to exercise in the obese rats. Int $\mathbf{J}$ Obes Metab; 28(8): 972-8.

7. Daily JW, Hongu, N, Mynatt RL and Sach, DS (1998): Choline supplementation increases tissue concentrations of carnitine and lowers body fat in guinea pigs. J Nutr Biochem; 9: 464-70.

8. Daily $\mathbf{J}$ and Sachan $\mathbf{S}$ (2005): Choline supplementation alters carnitine homeostasis in human and guinea pigs. J. Nutr ; 135: $1938-44$

9. Decombaz J, Gmuender B, Sierro G and Cerretelli P (1999): Muscle carnitine after strenuous endurance exercise . J. Appl Physiol; 72: 423-7.
10. Dodson L and Sachan S (2004): Choline supplementation reduces urinary carnitine excretion in humans. Am J Clin Nutr; 63:

904-10.

11. Ellefson R,and Caraway T (1976): Lipids and lipoproteins fundamentals of clinical chem. P: 492-94. W.B. Saunder Co. Philadelphia.

12. Flores B, Faria C, Ueno M,and Saad J (2006): Exercise improves insulin and leptin sensitivity in hypothalamus of Wister rats. Diabetes; 55 (9) : 2554-61.

13. Gielgel J Ham A, and Clema W (1975): Manual and semiautomatic procedure for measurement of triglycerides in serum. Clin. Chem. Acta., $21: 1575-81$.

14. Heo K, Oldle J, Han IK, Cho W, Seo VE and Pikington DH (2000): Dietary Lcarnitine improves nitrogen utilization in growing pigs fed low energy, fat containing diets. J. Nutr., 130: 1809-1814.

15. Hongu $\mathbf{N}$ and Sachan DS (2003) : Carnitine and choline supplementation with exercise alter carnitine profiles and serum leptin concentration in healthy women. J. Nutr ., 133: 84-89.

16. Hongu $\mathbf{N}$ and Sachan DS (2005): Caffeine, carnitine and choline supplementation of rats decreases body fat and serum leptin concentration as does exercise . J. Nutr ; 135: 152-157.

17. Iossa S, Maria P, Lilla L, Raffaella C, and Giovanna $L$ (2002): Aretyl-LCarnitine supplementation differently influences nutrient partitioning, serum leptin concentration and skeletal muscle, mitochondrial respiration in young and old rats. J. Nutr; 132: 636-42.

18. Janne ER, Sigmund AA, Kari S and Christian AD (2001): Effect of long-term changes in diet and exercise on plasma leptin concentration. Am. J. of Clinical Nutrition; 73 (2) : 240-5.

19. Lau R, Blinu WD Bonen A and Dyck DJ (2001) Stimulatory effects of leptin and muscle contraction on fatty acid metabolism are not additive. Am J Physil Endocrinol Metab; 281 (1): 122-9.

20. Leiber S, Rdoin J, Liz J and Fasulo J (2002): Phosphatidylcholine protects against fibrosis and cirrhosis in the baboon. Gastroenterol; 106: 161-8.

21. Levin B and Meynell A (2006): Differential effects of exercises on body weight gain and adiposity in rats. Int. $\mathbf{J}$. Obes; 30(4) 722-727. 


\section{Neamat E. Hishem et al}

22. Kimura M, Tateishi N, Yada $\mathbf{E}$ and Suzuki M (2006): Adiponectin is regulated by exercise than food restriction in obese rats. Life Sci; 79 (22):2105-11.

23. Kraemer R,Chu H,and Castra V (2002):Leptin and exercise. Experim Biol Med; 227 (9):701-8.

24. Ma, Zhongmin, et al (1996): Radioimmunoassay of leptin in human plasma. Clinical Chemistry; 42:942-946.

25. Mcclell G, Kraft C and Michaud D (2004): Leptin and the control of respiratory gene expression in muscle. Biochem Biophy Acta; 20 (1): 86-93.

26. Neumann, G. (2005): Effects of Lcarnitine on athletic performance. Carnitine pathophysiological basic and clinical application. Seim H.\& Loster H. eds. P: 61- 71. Pnte Press Bochum, Germany.

27. Novak M. (1965): Calorimetric ultramicro method for the determination of free fatty acids. J. Lipid. Res; 6: 431-433.

28. Rein D. Krasin B and Sheard NF (2002):Dietary choline supplementation in rats increases carnitine concentration in liver, but decrease plasma and kidney carnitine concentration. J. Nutr. Biochem., 8: 68-73.

29. Robert $\mathbf{P}$, Hongnan $\mathbf{C}$ and Daniel $\mathbf{V}$ (2002): Leptin and exercise. Soc. Exp. Boil. Med., 227 : 701-708.

30. Romijn J, Goyle F Sidossis S , Endert E and Walfe $R$ (1999) :Regulation of endogenous fat and carrohydrate metabolism in relation to exercise. Am .J. Physiol ., 265: 80-91.

31. Sahtin K, Mogensen M, Bagger M, and Padersen PK (2006): Mitochondrial fat oxidation in skeletal muscle influences whole body fat oxidation during exercise. Am. J. Physiol. Endoc. Met., 22:121-9.

32. SaladinR,Devos,P. Guerre, M. Girard, J. and Auwer J (1999): Transient increase in obese gene expression after food intake or insulin administration. Nature; 377: 527-9.

33. Saldanda A, Rodrigue A, Nuvarro F. (2004): Carnitine supplementation fails to maximize fat mass loss induced by endurance training in rats. Ann. Nutr. Metab., 48 (2) : 90-99.

34. SAS(1997): SAS Institute Inc SAS User's Guide: statistics 1997 SAS Institute Cary, NC. 
تأثير التمرينات الرياضية الهوائية القصيرة مع تعاطي الكارنيتين و الكولين أو وأوني

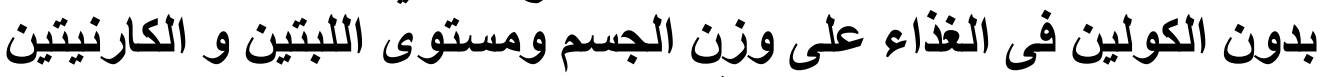
في مصل الدم وحالة الدهون في ذكور الجرذان

نعمات إبراهيم هاشم* و بشرى حسن الظواهرى* وسـهام محمد سعيد النقيب** ليلى عاطف أحمد** المرث*

قسمي الفسيولوجيا* و الكيمياء الحيوية*** كلية طب بنات ـ جامعة الأزهر - القاهرة

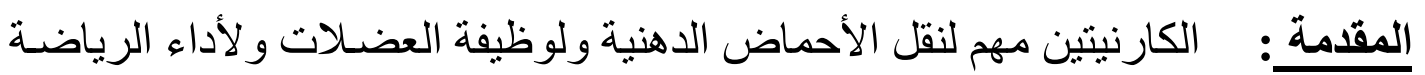

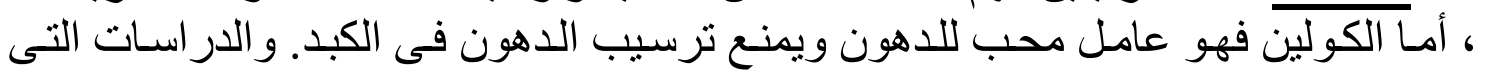

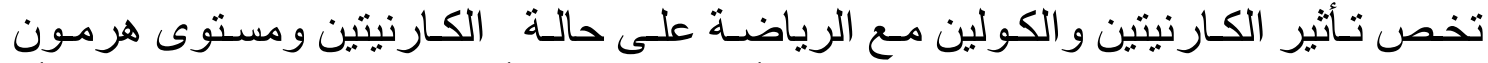

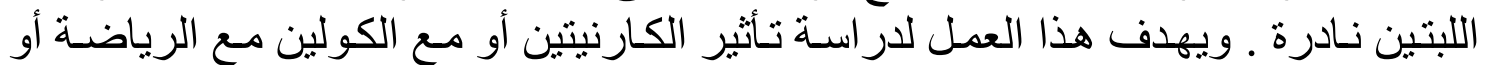

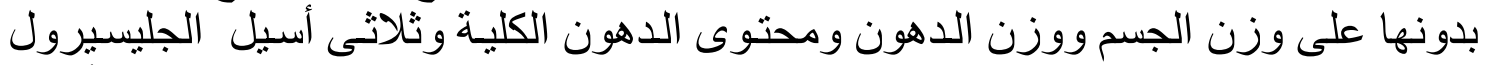

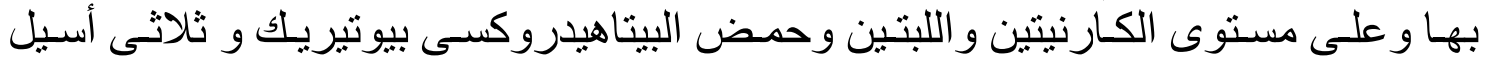

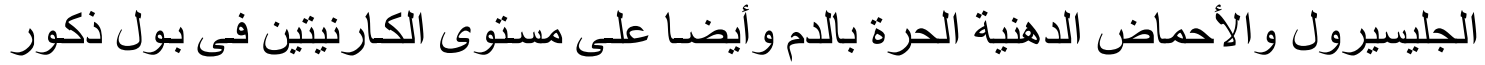

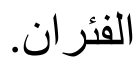

الطريقة: استخدم فى هذا العمل 48 فأر قسمت إلى المجمو عات التالية بالتسـاوى (16 فأر

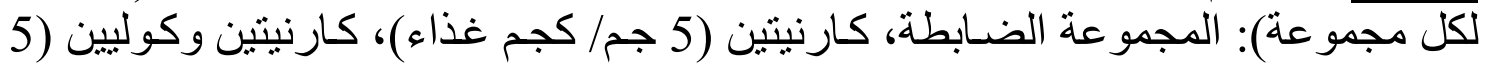

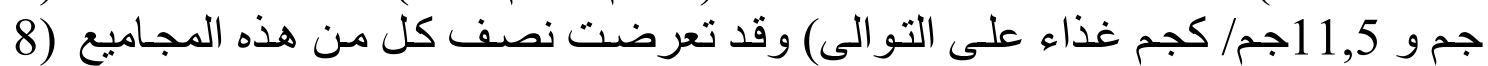

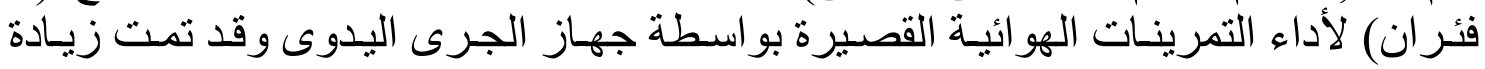

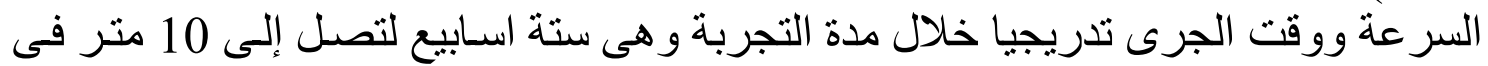

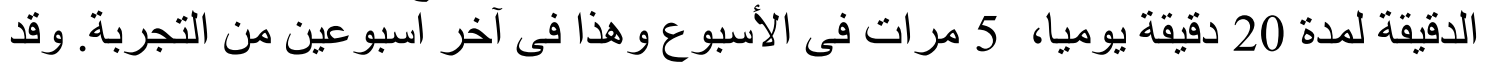

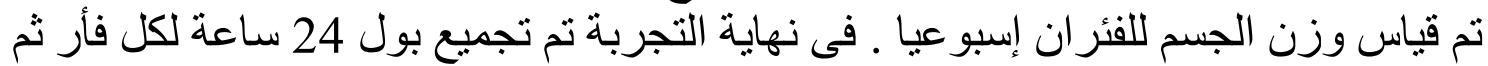

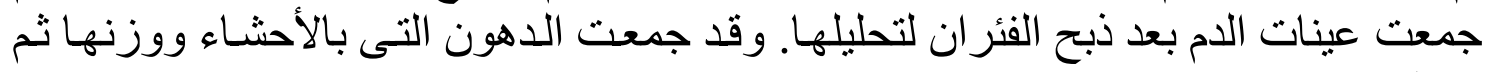

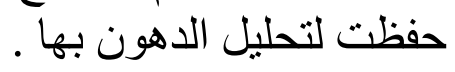

النتائج : تسبب الكارنيتين فى نقص طفيف بوزن الجسم ووزن الدهون ومحتوى ثناثى الإنى

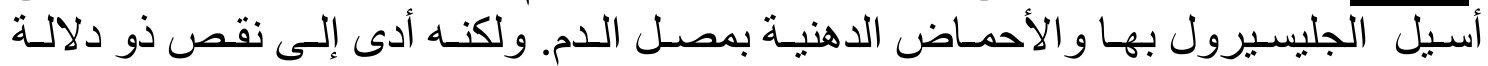

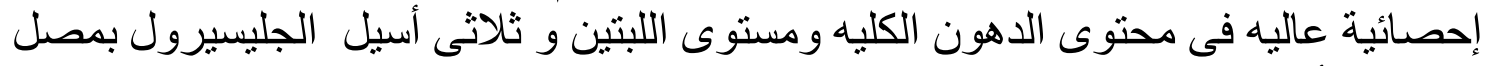

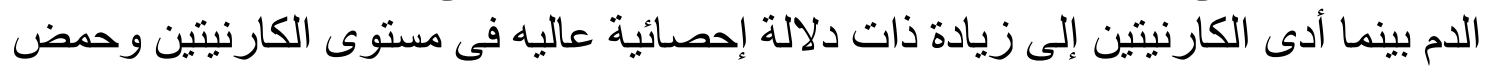

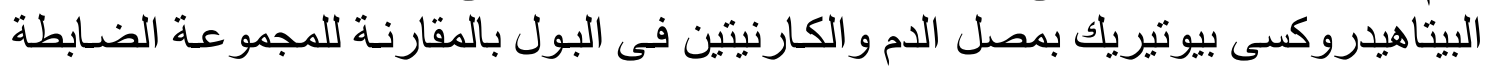

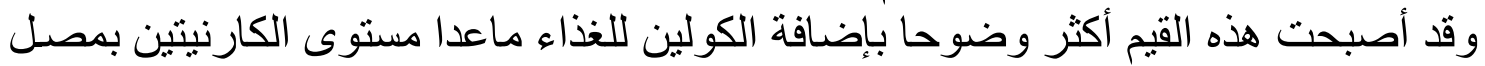

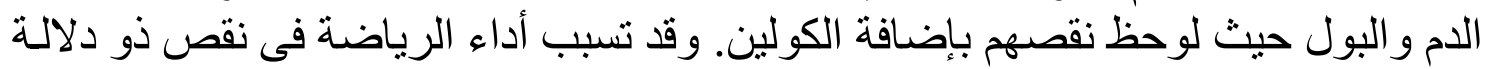

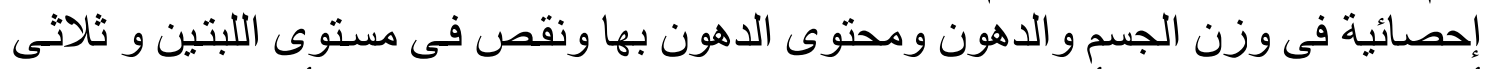

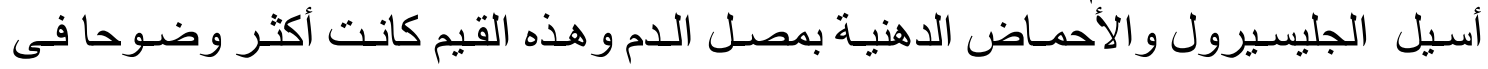




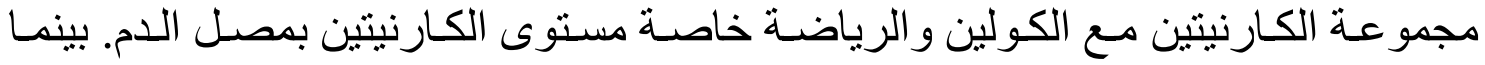

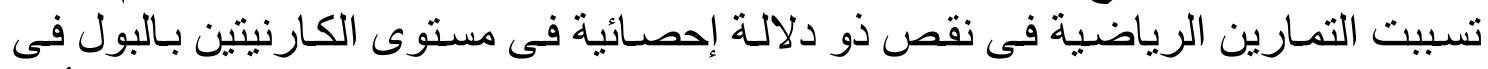

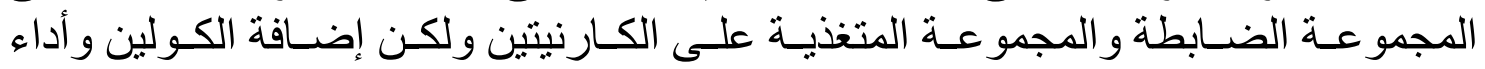

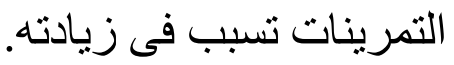

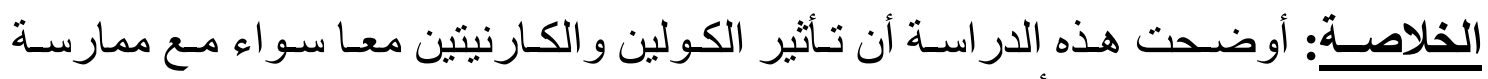

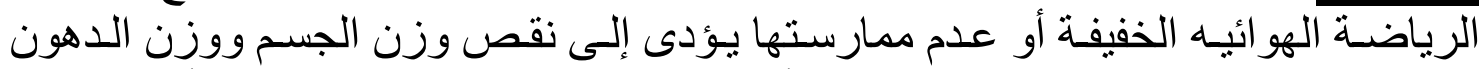

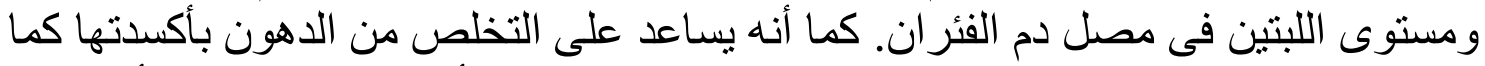

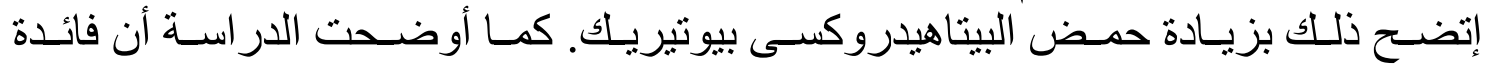

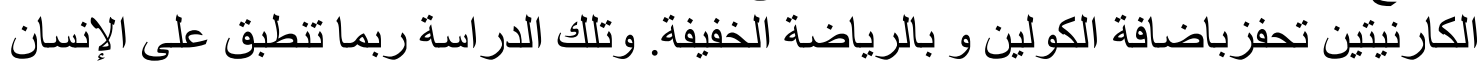

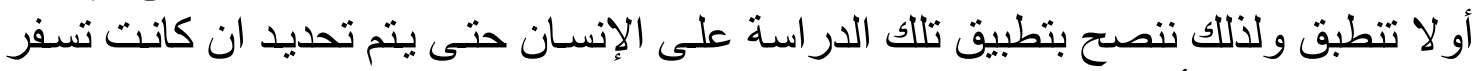

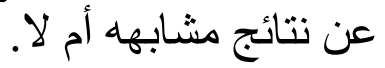

